\title{
M. C. Gatto, D. J. Mattingly, N. Ray, and M. M. Sterry (Eds.): Burials, Migration, and Identity in the Ancient Sahara and Beyond
}

\author{
Cambridge University Press, Cambridge, 2019, 561 pp., ISBN 978-1-108-47408-5
}

\section{Elizabeth A. Sawchuk (iD)}

Published online: 15 February 2020

(C) The Author(s) 2020

The diverse array of tombs, tumuli, and other funerary monuments that dot the Sahara makes it one of the most fascinating mortuary landscapes in the world. Such features also comprise a large part of the archaeological record of the last 5000 years. Yet mortuary archaeology tends to be regionally and chronologically fragmented across multiple countries with distinct academic histories and language traditions. Synthesizing burial traditions across thousands of years and $12,000,000 \mathrm{~km}^{2}$ is also no small task, which is why few sources have taken on the Sahara as a whole.

In Burials, Migration, and Identity in the Ancient Sahara and Beyond, Gatto, Mattingly, Ray, and Sterry bring together diverse datasets from all corners of the desert using an explicitly trans-Saharan approach. Inspired by developments in Mediterranean archaeology, they reframe the desert as a great interconnected sea that can only be understood in relation to its "shorelands" on its eastern, northern, and southern peripheries. Instead of standing outside the desert looking in, as scholars and historians have done for centuries, this book is set within the Sahara looking out. Through this approach, the editors seek to understand how events and processes

E. A. Sawchuk $(\bowtie)$

Department of Anthropology, Stony Brook University, Stony

Brook, USA

e-mail: elizabeth.sawchuk@stonybrook.edu

E. A. Sawchuk

Department of Archaeology, Max Planck Institute for the Science of Human History, Jena, Germany within this network shaped human lives across space and time.

The volume focuses on burial, migration, and identity, one of the four interdisciplinary areas explored by the Trans-SAHARA Project (2011-2017). The seventeen chapters are written by archaeologists, biological anthropologists, historians, and linguists who engage with these themes through a wide range of case studies. The aim is to critically discuss and compare evidence from across the desert for the first time. One of the ultimate objectives is to explore whether a trans-Saharan identity emerges that may help contextualize relationships and connections across this broader landscape.

By and large, the book is geographically organized. Following a comprehensive introduction led by D. J. Mattingly on the history of burial, migration, and identity research in the Sahara (which is an immensely valuable literature review), the book begins in the Central Sahara (Part I) with several chapters on Libya's Fazzan region. Chapter 2, also led by Mattingly, is a data-heavy synthesis of $>11,000$ surveyed and $>150$ excavated Garamantian tombs studied by the Desert Migrations Project 2007-2011, and includes extensive descriptions of architecture, funerary furniture, grave goods, burial orientations, and human remains. M. C. Gatto and colleagues then compare these data to mortuary patterns and burial typologies in the southwestern Fazzan attributed to Garamantian contemporaries, the Atarantes. The section's final chapters provide regional perspectives on human mobility and identity through cranial morphometrics and stable isotope analysis led by R. K. Power, and skeletal analysis led by F. Ricci. 
From the Central Sahara, the book casts views to the east, north, west, and south, respectively. D. N. Edwards begins "Looking East" (Part II) by synthesizing mortuary research between the Nile and Sahara, describing a situation in which thousands of graves have been excavated, yet there is pressing need for more context on these features and better approaches and scales of analysis. M. Buzon and colleagues follow with a comprehensive review of isotopic approaches to mobility within this regional context, which the editors later emphasize is the largest published $\delta^{18} \mathrm{O}$ dataset from North Africa to date.

In "Looking North" (Part III), J. Sanmartí and colleagues review pre-Roman monuments from the first millennium $\mathrm{BC}$ in the eastern Maghrib linked to $\mathrm{Nu}-$ midian populations, highlighting unusual secondary burial practices and foci for future work. Pivoting to the same time period in Morocco, E. Papi uses mortuary evidence to argue against prevailing views of LibycoPhoenician colonization, emphasizing local continuity among rituals and burial traditions.

Remaining in Morocco, "Looking West" (Part IV) begins with Y. Bokbot's analysis of protohistoric and pre-Islamic funerary sites as evidence that the region was open to cultural influences from the Sahara, Maghrib, and sub-Saharan Africa. J. Clarke and N. Brooks argue that the Western Sahara was likewise in contact with the Central Sahara and potentially Iberia and the North Atlantic, with key archaeological evidence concentrated along inland drainage systems.

Finally, "Looking South" (Part V) begins with an extensive review of burial practices in the first and early-second millennium at Kissi, Burkina Faso. S. Magnavita argues for long-term continuity in mortuary customs from the Later Stone Age to Iron Age, despite some individuals adopting foreign trends, likely to express economic or social status. S. MacEachern concludes the section by tackling mid-Holocene cultural change in the Lake Chad Basin as communities shifted from pastoralism to sedentary agriculture. Pulling together data from four countries spanning Germanic, Anglophone, and Francophone research traditions, this beautifully written chapter epitomizes the challenges faced by those interested in broader regional processes in Saharan prehistory.

Finally, Part VI departs from geography to consider how linguistic evidence contributes to themes of burial, migration, and identity, with some dissent among contributors. R. Blench opens with a thorough review of current knowledge, unanswered questions, and persistent challenges in tracing Saharan languages. Languages spoken today have been strongly shaped by religious and political movements over the last millennium and represent a fraction of past diversity, leaving only breadcrumbs for those interested in ancient linguistic distributions. In the following chapters, C. Ehret and E. Fentress focus on the Berber branch of the Afroasiatic family. Ehret, a linguist, identifies three deep subbranches and proposes a chronology for its expansion beginning with an early initial divergence in the second millennium $\mathrm{BC}$. He also uses the linguistic toolkit to speculate on proto-Berber life, specifically when people began keeping livestock and potential archaeological correlates. Fentress, an archaeologist, goes on to write a "(pre)historical novel" showing how Ehret's early chronology could fit with archaeological and historical evidence, proposing recurrent population movements from east to west. Models presented in this section are tenuous, but they include testable hypotheses that should be incorporated into future research.

Although the authors reference other chapters throughout, it is the discussion led by M. Sterry that ultimately pulls the volume together. The final chapter presents "irrefutable evidence of links and connections that serve to define a Trans-Saharan zone at an early date," with migration and mobility creating a network of shared culture. This includes a number of shared funerary practices between ca. $1000 \mathrm{BC}$ and $1000 \mathrm{AD}$, such as individual burial beneath circular stone-built monuments and a wide distribution of drum tombs and cairns. Regionally distinct trajectories within these traditions, for example, with the Garamantes, retain ties to an interconnected Saharan world. The chapter also summarizes findings on burial landscapes, patterns of migration and mobility, and reconstructing identity at various scales.

Of the volume's three themes - burial, migration, and identity - burial receives the most attention and represents the greatest contribution. Compiling the history of mortuary research, key findings, major challenges, and future directions for over a dozen northern African countries is enough to put this book on any Africanist's shelf. Many chapters also contain a wealth of previously unpublished data, photos, drawings, and detailed maps prime for comparative research. Although chapters tend to be focused on broad themes, poignant individual stories also come through, such as the young woman with a lip plug in the Fazzan who hints at sub-Saharan connections (Chapter 2) and a child with over 4000 
beads and cowrie shells at Daima who signals an important social shift (Chapter 13).

Migration and to a lesser extent identity are interwoven throughout, with several isotope- and linguisticfocused chapters explicitly engaging with population movements. Because research has historically focused on mortuary typologies, there is enormous potential for future bioarchaeological and biomolecular work on the skeletons described throughout this volume. Isotopic analyses show promise for larger studies, which should follow the integrated bioarchaeological approach articulated by Buzon and colleagues in Chapter 7 .

Several authors lament poor skeletal preservation, particularly the difficulty obtaining collagen for $\delta^{15} \mathrm{~N}$ values and ancient DNA, but this may be overly pessimistic. Recent ancient DNA research in North Africa by Fregel et al. (2018) and van de Loosdrecht et al. (2018), as well as work in eastern Africa where skeletal preservation is also poor (Prendergast et al. 2019), indicates methodological advances are opening up new possibilities. This volume will be an important resource for any future research along those lines. Biomolecular work must be integrated within existing archaeological and linguistic frameworks that recognize the complexity and plurality of identities and reject simplistic affiliations and explanations for population movements.

Finally, troubles of the past and present are subtle undercurrents throughout the book. Archaeological research in many Saharan countries extends back over a century with early excavations focused on tombs, often to the exclusion of other evidence. This has produced a situation of widely divergent data collection methods, standards, and foci for past research - a common problem in African (and perhaps most) archaeology. This book represents a major effort to collate and synthesize previous work to facilitate analysis across colonial boundaries and multi-lingual academic literatures.

A second thread concerns current geopolitical unrest. Notably, the ongoing conflict in Libya significantly impacted research by Power and colleagues, limiting them to previously collected data and a small amount of skeletal material curated abroad. Current inaccessibility of much of the Sahara necessitates new approaches, with authors like Edwards recommending a shift to remote sensing and GIS to study burial landscapes. As stated by the editors, such realities make this a "suitable juncture" to pause, take stock of past work, and consider which questions and approaches to pursue next. I agree that this is a turning point, and hope the path for future work laid out in this volume can be realized sooner than later.

Funding Information Open access funding provided by Projekt DEAL.

Open Access This article is licensed under a Creative Commons Attribution 4.0 International License, which permits use, sharing, adaptation, distribution and reproduction in any medium or format, as long as you give appropriate credit to the original author(s) and the source, provide a link to the Creative Commons licence, and indicate if changes were made. The images or other third party material in this article are included in the article's Creative Commons licence, unless indicated otherwise in a credit line to the material. If material is not included in the article's Creative Commons licence and your intended use is not permitted by statutory regulation or exceeds the permitted use, you will need to obtain permission directly from the copyright holder. To view a copy of this licence, visit http://creativecommons.org/licenses/by/4.0/.

\section{References}

Fregel, R., Méndez, F. L., Bokbot, Y., Martín-Socas, D., Camalich-Massieu, M. D., Santana, J., Morales, J., ÁvilaArcos, M. C., Underhill, P. A., Shapiro, B., Wojcik, G., Rasmussen, M., Soares, A. E. R., Kapp, J., Sockell, A., Rodríguez-Santos, F. J., Mikdad, A., Trujillo-Mederos, A., \& Bustamante, C. D. (2018). Ancient genomes from North Africa evidence prehistoric migrations to the Maghreb from both the Levant and Europe. Proceedings of the National Academy of Sciences, 115, 6774-6779.

Prendergast, M. E., Lipson, M., Sawchuk, E. A., Olalde, I., Ogola, C. A., Rohland, N., Sirak, K. A., Adamski, N., Bernardos, R., Broomandkhoshbacht, N., Callan, K., Culleton, B. J., Eccles, L., Harper, T. K., Lawson, A. M., Mah, M., Oppenheimer, J., Stewardson, K., Zalzala, F., Ambrose, S. H., Ayodo, G., Gates, H. L., Gidna, A. O., Katongo, M., Kwekason, A., Mabulla, A. Z. P., Mudenda, G. S., Ndiema, E. K., Nelson, C., Robertshaw, P., Kennett, D. J., Manthi, F. K., \& Reich, D. (2019). Ancient DNA reveals a multistep spread of the first herders into sub-Saharan Africa. Science, 365, eaaw6275.

van de Loosdrecht, M., Bouzouggar, A., Humphrey, L., Posth, C., Barton, N., Aximu-Petri, A., Nickel, B., Nagel, S., Talbi, E. H., El Hajraoui, M. A., Amzazi, S., Hublin, J.-J., Pääbo, S., Schiffels, S., Meyer, M., Haak, W., Jeong, C., \& Krause, J. (2018). Pleistocene North African genomes link near eastern and sub-Saharan African human populations. Science, 360, $548-552$.

Publisher's Note Springer Nature remains neutral with regard to jurisdictional claims in published maps and institutional affiliations. 